\title{
WHAT IS MORMON TRANSHUMANISM?
}

\author{
By Lincoln Cannon
}

\begin{abstract}
Mormon Transhumanism is the idea that humanity should learn how to be compassionate creators. This idea is essential to Mormonism, which provides a religious framework consistent with naturalism and supportive of human transformation. Mormon Transhumanists are not limited to traditional or popular accounts of religion, and embrace opportunities and risks of technological evolution. Although usually considered secular, Transhumanism has some religious origins and sometimes functions as religion. Accelerating change contextualizes a Mormon Transhumanist narrative of common expectations, aspirations, and parallels between Mormonism and Transhumanism. Mormon Transhumanism has produced secular arguments for faith in God and religious arguments for Transhumanism.
\end{abstract}

Transhumanism is a new paradigm for thinking about the future of humanity. ${ }^{1}$ As Transhumanists, we have discarded the old assumption that human nature is or ever was static, not only because science demonstrated biological evolution, but especially because history itself is cultural and technological evolution. Although diverse in background and perspective, our common expectation is that humanity will continue to evolve. Our common ambition is to inject ourselves into the evolutionary process, changing our bodies and minds, our relationships, and even our world for the better - perhaps to learn, love, and create together indefinitely. ${ }^{2}$

Transhumanism may be the most dangerous idea. ${ }^{3}$ The risks are as horrible as the opportunities are wonderful. Even acknowledging concerns and emphasizing ethics, we might agree with our critics that we are trying to play God. After all, what are the alternatives? What prospects for children that would not try to play adult? That would not grow from trying to learning? Would not mature from playing to being? Surely their nursery will prove too small, even for the smallest of the living. But for us, who know we are not dead as yet, why not believe the most dangerous idea? Why not live?

Whatever the secular response, perhaps properly excusing itself from vying for the high spirit of humanity, the Mormon Transhumanist response is a quickened heart and brightened eyes. We have heard this story before. ${ }^{4}$ This is our calling and our choice has not changed. ${ }^{5}$ Children of God would try to play God, and more. We would learn how to be God. Dangerous indeed, and worthy of exquisite caution and utmost reverence. But for the child, there is no other way. Mormon Transhumanism stands for the idea that humanity should learn how to be God, ${ }^{6}$ and not just any kind of god, not a god that would raise itself in hubris above others, ${ }^{7}$ but rather the God that would raise each other together as compassionate creators.

\footnotetext{
${ }^{1}$ Nick Bostrom, "What Is Transhumanism?," accessed 1 November 2014, http://www.nickbostrom.com/old/transhumanism.html.

2 “Transhumanist FAQ," Humanity+, accessed 1 November 2014, http:/humanityplus.org/philosophy/transhumanist-faq/.

${ }^{3}$ Francis Fukuyama, "Transhumanism - the World's Most Dangerous Idea," accessed 1 November 2014, http://www.au.dk/fukuyama/boger/essay/.

${ }^{4}$ Moses 4: 1-3

${ }^{5}$ Abraham 3: 24-27

${ }^{6}$ Joseph Smith in Teachings of the Prophet Joseph Smith, ed. Joseph Fielding Smith (Salt Lake City: Deseret Book, 1938), 346.

${ }^{7} 2$ Thessalonians 2: 3-4
} 
${ }^{8}$ Humanity should learn how to be Christ. ${ }^{9}$

\section{MORMONISM}

Mormonism itself is an immersive discipleship of Jesus Christ. ${ }^{10}$ It is not so much a religion about Jesus as it is an aspiration to live the religion of Jesus. ${ }^{11}$ With Jesus, ${ }^{12}$ we would trust in, ${ }^{13}$ change toward,${ }^{14}$ and fully immerse our bodies and minds in the role of Christ. ${ }^{15}$ We would be messiahs, ${ }^{16}$ saviors for each other, ${ }^{17}$ consoling and healing and raising,${ }^{18}$ as exemplified and invited by Jesus. ${ }^{19}$ We would also endure in that role ${ }^{20}$ working to reconcile ourselves with our relations and world, ${ }^{21}$ through suffering and even death if needed, ${ }^{22}$ anticipating the prophesied day of transfiguration and resurrection to immortality in eternal life. ${ }^{23}$ So while Mormons may not be Christian by creed, ${ }^{24}$ we are plainly Christian by Gospel. ${ }^{25}$

Joseph Smith was born in the state of New York in $1805 .{ }^{26}$ Joseph, as he liked to be called, spoke and wrote about visions and revelations from God, beginning in adolescence and throughout his life. In 1830, Joseph published the Book of Mormon. He described the book as a revealed translation from engravings on golden plates by an ancient American prophet named Mormon, who had compiled a religious history of his people, including a visit from the resurrected Jesus Christ. Soon after publishing the book, Joseph founded the Church of Christ to be a restoration of primitive Christianity. The church grew quickly, amidst controversy and sometimes violent persecution, until a mob killed Joseph in 1844, and the already-strained church fractured.

Brigham Young emerged as the recognized leader of the majority of Mormons, who he led across the plains and mountains of the American west to settle in what has become the state of Utah. There, in 1851, he incorporated The Church of Jesus Christ of Latter-day Saints, which now consists of over 15 million members around the world. ${ }^{27}$ Many Mormons that did not follow Brigham Young eventually coalesced around the leadership of Joseph Smith III, the oldest surviving son of Joseph Smith. In 1860, he established The Reorganized Church of Jesus Christ of Latter-day Saints, which changed its name in 2001

\footnotetext{
${ }^{8}$ Romans 8: 16-17

${ }^{9}$ Colossians 1: 27

${ }^{10} 2$ Nephi 25: 26

${ }^{11}$ D\&C 93: $19-20$

${ }^{12} 2$ Nephi 31: 5-13

${ }^{13}$ Ether 13: 4

${ }^{14} 3$ Nephi 11: 37-40

${ }^{15}$ Mosiah 5: 9

${ }^{16} 2$ Corinthians 1: 21

${ }^{17}$ D\&C 103: 9

${ }^{18}$ Matthew 10: 8

${ }^{19}$ John 14: 12

${ }^{20} 2$ Nephi 31: 16-21

${ }^{21} 3$ Nephi 12: 21-24

${ }^{22}$ D\&C 138: 11-14

${ }^{23}$ D\&C 63: 49-52

${ }^{24}$ Joseph Smith History 1: 19

${ }^{25}$ Mormon 7: 8-9

${ }^{26}$ Richard Bushman, Joseph Smith: Rough Stone Rolling (New York: Random House, 2005).

27 "Facts and Statistics," The Church of Jesus Christ of Latter-day Saints, accessed 1 November 2014, http://www.mormonnewsroom.org/facts-and-stats.
} 
to Community of Christ, and today consists of over 250,000 members. ${ }^{28}$ In addition to these large Mormon denominations, there are numerous small denominations, such as the Fundamentalist Church of Jesus Christ of Latter-day Saints, which continues to practice polygamy, unlike most other Mormon denominations.

Mormonism posits a metaphysics, in contrast to classical substance dualism, that is consistent with some accounts of physicalism and naturalism. According to our scriptures, everything is material, including our minds $;{ }^{29}$ and everything is embodied, including God. ${ }^{30}$ Moreover, God did not create matter. ${ }^{31}$ Instead, as Joseph described it, God was once as we are now: finding ourselves in the midst of minds and matter, instituting new laws within the context of existing laws, and organizing the world out of chaos. ${ }^{32}$ In other words, God became God, ${ }^{33}$ and it was not the first time - nor should it be the last.

Mormonism offers a theodicy that explains evil as an unavoidable risk inherent in any opportunity to create more genuine creators. ${ }^{34}$ At a grand council in heaven before the creation of this world, the children of God presented two plans. ${ }^{35}$ One plan would optimize for thriving cultivation. The other would optimize for suffering mitigation. The first would be challenging, with wonderful joy and terrible misery: new angels and demons, new gods and devils, even a new Christ and a new Satan. The second would be easy. No real losses, and yet no real gains. As the story goes, God chose the first and war ensued, continuing to this day. ${ }^{36}$

Mormonism projects an eschatology of transformation, of the Earth into heaven, ${ }^{37}$ and of humanity into God, ${ }^{38}$ and would thereby provoke us to fervent participation in its narrative. ${ }^{39}$ Our scriptures situate us in a time of rapid progress, ${ }^{40}$ apocalyptic risk, and millennial opportunity. ${ }^{41}$ It culminates in the return of Christ, not as a solitary wanderer, but like the rising sun for all to see, ${ }^{42}$ and for all to be like. ${ }^{43}$ The scriptures go on to describe a Millennial Earth, beyond present notions of poverty or death, where the living are transfigured and the dead are resurrected to immortality. ${ }^{44}$ Then the Earth itself is transfigured, ${ }^{45}$ becoming like a crystal globe, a sea of glass and fire, where all things are manifest: past, present, and future. ${ }^{46}$ Its inhabitants receive the full grace and power of God, ${ }^{47}$ and they learn of a yet higher order of

28 "General Denominational Information," Community of Christ, accessed 1 November 2014, http://www.cofchrist.org/pr/GeneralInfo.asp.

${ }^{29}$ D\&C 131: 7

${ }^{30}$ D\&C 130: 22

${ }^{31}$ D\&C 93: 23, 29, 33

${ }^{32}$ Smith in Teachings, 354.

${ }^{33}$ Smith in Teachings, 345-346.

${ }^{34} 2$ Nephi 2: 11

${ }^{35}$ Moses 4: 1-3 and Abraham 3: 24-28

${ }^{36}$ Revelation 12: 7-9

${ }^{37} \mathrm{D} \& \mathrm{C}$ 88: $25-26$

${ }^{38}$ D\&C 132: 20

${ }^{39}$ D\&C 43: 23-25

${ }^{40}$ D\&C 88: 73-80

${ }^{41}$ D\&C 43: 26-33

${ }^{42}$ Joseph Smith Matthew 1: 25-26

${ }^{43}$ Moroni 7: 48

${ }^{44}$ D\&C 101: 26-34

${ }^{45}$ D\&C 63: 20-21

${ }^{46}$ D\&C 130: 6-9

${ }^{47}$ D\&C 76: 92-95 
worlds. $^{48}$

\section{POSTSECULAR RELIGION}

For some, God is not a living proposition, let alone prophecy or religion. They wonder if we have not heard that God is dead, ${ }^{49}$ and they are right to wonder. Following their Gods, traditional religions appear to be dying, particularly in technologically advanced and prosperous places.$^{50}$ Observing this, many have embraced the secularization hypothesis that religion itself is dying. However, that hypothesis is showing its age, embraced more by anti-religious voices in popular culture than by careful students of the religious phenomenon, among whom another hypothesis is gestating. ${ }^{51}$

If God is merely a supernatural superlative, he very well may be dead, but positing such as God misses the practical function of God. God always has been and is at least a posthuman projection, an extension and negation of human desire, imagined and expressed within the constraints of human thought, language, and action. ${ }^{52}$ That is not to say God is only so much. To the contrary, we may have moral and practical reasons to trust that others have already realized posthuman projections ${ }^{53}$ However, no matter your attitude toward faith, God is at least this much: a posthuman projection. Understood in terms of that function, God clearly is not dead and never was, except perhaps to the extent recurring death is part of evolution, including that of God.

If prophecy is merely fortune-telling, it too may be dying, but that also fails to account for function. Whether or not it becomes fore-telling, prophecy is always forth-telling: a socially interactive work of inspiration, even provocation, that would steer us from perceived risks toward desired opportunities. At its best, it is a persuasive expression of compassion, even if punctuated with serious warnings, aimed at a shared sublime potential, not as narrowly preconceived, but rather as openly imagined from a position that would transcend itself in genuine creation. But to function with power, prophecy must be connected, in the heart and mind of its recipient, with living possibilities, especially pressing necessities and urgencies. Prophecy matters, becoming fore-telling from forth-telling, only to the extent it reaches into us and changes our thoughts sufficiently to change our words and actions, which just might change our world.

Likewise, if religion is merely genuflection to the supernatural, it very well may be dying, but again that overlooks function. Many of us have regarded religion narrowly, and much that is supposed to be secular may actually function as religion. ${ }^{54}$ For example, some claim inspiration from science or ethics. Awe fills us as we contemplate the vastness of space or the voice of the people. Yet the inspiration is not merely in the reductionist implications of science or the procedural adjudications of ethics. Rather esthetics are woven through them, tying them together in meaning, and that is why we care about science or ethics. Esthetics shape and move us, and at their strongest, they provoke us as a community to a strenuous mood.

\footnotetext{
${ }^{48}$ D\&C 130: 10

${ }^{49}$ Friedrich Nietzsche, Thus Spake Zarathustra (New York: Dover Publications, 1999), 3.

${ }^{50}$ James Smith, "Secular Liturgies and the Prospects for a Postsecular Sociology of Religion," The Postsecular in Question and Religion in Contemporary Society (2012), 159-184.

${ }^{51}$ Jurgen Habermas, "Notes on Post-Secular Society," New Perspectives Quarterly (2008), 25: 17-29.

${ }^{52}$ Sigmund Freud, Civilization and Its Discontents (New York: Norton, 1961), 45.

${ }^{53}$ Lincoln Cannon, "Theological Implications of the New God Argument," Parallels and Convergences: Mormon Thought and Engineering Vision (Draper, Utah: Greg Kofford Books, 2012).

${ }^{54}$ John Milbank, Theology and Social Theory: Beyond Secular Reason (New Jersey: Wiley-Blackwell, 2006).
} 
${ }^{55}$ When they do that, they function as religion, not necessarily in any narrow sense, but esthetics that provoke a communal strenuous mood may be understood to function as religion from a postsecular vantage point. ${ }^{56}$

Of course, none of this means science or ethics should or even could be displaced by religion. To the contrary, science should continue to reconcile our contending accounts of experience, as ethics should our contending accounts of desire.$^{57}$ Each should expand its reach to the uttermost, ${ }^{58}$ always better informing our esthetics, affecting each other in a feedback loop..$^{59}$

Yet even as science and ethics increasingly empower us, we should not fool ourselves into supposing they will ever be finished or sufficient in themselves. ${ }^{60}$ It is not enough that we can describe our world through science or imagine a better world through ethics. We also want to make a better world. We can do that through engineering and governance, but it is also not enough that we can make a better world. We want to feel it, sometimes powerfully, and more: we want to share our powerful feelings with others in ways that move us together. As engineering and governance are action on science and ethics, religion is action on esthetics. As engineering and governance are the power of science and ethics, religion is the power of esthetics.

We care for and use science and ethics only in accordance with esthetics, which presents itself as foremost among them in the most vital moments of life, when we we must act, according to whatever wisdom and inspiration we might have. Life cannot wait. ${ }^{61}$ How will we act? Will we see beauty in science? Will we feel unity in ethics? Will we care, and how much will we care? Could our degree of concern make a practical difference? These questions matter to all except perhaps the most apathetic, escapist, or nihilistic among us. Their answers scope our future.

If we can raise our eyes from the altar of religious and anti-religious dogma, we will see that the hand raised to finish the dying God is the sign of the oath to the resurrecting God. If we can keep our eyes raised, resisting the carnage below, we will also see the hand is our own and it holds a blade that is aged and stained. That is when we have a choice, either to repeat the old sacrifices of our ancestors, or finally to make the new sacrifice that they always implied: we can put ourselves on the altar and learn how to be God. We can recognize that negation of one posthuman projection always implies another, misrecognized until humanity embraces its transformation. ${ }^{62}$

\section{TECHNOLOGICAL EVOLUTION}

For some, the idea of transformation into posthumanity conjures images of comic book cyborgs with gun arms and laser eyes. But most would agree that gun arms and laser eyes would not be particularly

\footnotetext{
${ }^{55}$ William James, The Will to Believe, and Other Essays in Popular Philosophy, and Human Immortality (New

York: Dover Publications, 1956), 213.

${ }^{56}$ Smith, "Secular Liturgies."

57 James, The Will to Believe, and Other Essays in Popular Philosophy, and Human Immortality, 190.

${ }^{58}$ Sam Harris, The Moral Landscape: How Science Can Determine Human Values (New York: Free Press, 2010).

${ }^{59}$ Albert Einstein in The Private Albert Einstein (Kansas City, Missouri: Andrews and McMeel, 1992 ), 85.

${ }^{60}$ Emile Durkheim, Elementary Forms of Religious Life (Oxford University Press, 1912), 325-327.

${ }^{61}$ Durkheim, Elementary Forms of Religious Life.

${ }^{62}$ Hava Tirosh-Samuelson, “Transhumanism as a Secularist Faith,” Zygon (2012), 47: 710-734.
} 
desirable transformations, either practically or esthetically. For better examples, look at the technology that is transforming you right now. You may be using a computing device to extend your ability to communicate. You may be reading through glasses, contacts, or surgically-modified eyes, or listening through hearing aids or cochlear implants. You are probably wearing clothing to enhance your ability to adapt to environmental change. Under those clothes, you might have implants or prosthetics. Through your blood, drugs may be relieving pain, heightening attention, or facilitating growth. That is just now. Think through the rest of the day leading up to this moment. Think through your life. Consider human history. If technologically-enhanced humans are cyborgs then we have always been cyborgs ${ }^{63} \mathrm{We}$ have always been transforming humans, transhumans, and to the extent we have welcomed that, we have been implicit Transhumanists. At least in context of the past and present, that is not particularly controversial.

The controversy arises when we look forward. How will technology change us in a few years or decades? ${ }^{64}$ What about a thousand years from now? How many drugs, surgeries, prosthetics, and other changes are there between humans and posthumans, as different from us as we now are from our prehuman ancestors? Is it possible to change that much? If so, should we?

Sometimes we talk about humans becoming more robotic or robots becoming more human. When thinking of robots, we might feel cold metal or hollow plastic. If that is what robots are then we are not and never should (or could meaningfully) be robots. However, such language relies on a dichotomy that is increasingly insufficient for describing not only the possibility space, but even the actuality space. Does a human receiving a prosthetic limb or an artificial heart become less human? Can a body originating from artificial DNA, conceived through an artificial process, or gestated in an artificial environment ever be human, even if it is practically indistinguishable from natural humans? For that matter, how natural are humans? Are agriculture and medicine natural? The blurring between natural and artificial is as ancient as the stick our distant ancestor wielded to extend her reach, and the leaves donned to enhance his skin. In an important sense, a synthesis of anatomy and tools is part of what made us human, empowering us above and differentiating us from our prehuman ancestors. In that sense, perhaps we have always been robots, for at least as long as we have been humans.

Why do we want to enhance ourselves? The answer is not new. We want to enhance ourselves for all the reasons we have made tools since the beginning of history. Tools empower us. So we will continue to build more and better tools, and their synthesis with our anatomies will become increasingly seamless and intimate, because we want to and because we can, for the power it provides. Like all power, tools and their intimate evolution into body and mind enhancements are not inherently good or evil. Rather, they are both risks to mitigate and opportunities to pursue according to whatever wisdom and inspiration we might have. On the one hand, tools can empower us against each other. Some hoard, and others deplete. Elites form, totalitarians control, and tyrants oppress. Artificial catastrophic risks well beyond those of nuclear weapons present themselves. ${ }^{65}$ Perhaps we could realize our worst imaginations of the Apocalypse. On the other hand, tools can also empower us for each other. Already we have used them to build, relate, console, and heal in ways our distant ancestors imagined only God to have the capacity. ${ }^{66}$ Perhaps someday we might transfigure ourselves into ageless bodies. ${ }^{67}$ We might even raise each other as

\footnotetext{
${ }^{63}$ Brenda Brasher, "Thoughts on the status of the cyborg: on technological socialization and its link to the religious function of popular culture," Journal of the American Academy of Religion (1996), 64: 809-830.

${ }^{64}$ Ray Kurzweil, The Singularity is Near (New York: Penguin Books, 2005).

${ }^{65}$ Nick Bostrom, Global Catastrophic Risks (Oxford University Press, 2008).

${ }^{66}$ Steven Pinker, The Better Angels of Our Nature: Why Violence Has Declined (New York: Penguin Books, 2011).

${ }^{67}$ Aubrey de Grey, Ending Aging: The Rejuvenation Breakthroughs that Could Reverse Human Aging in Our
} 
sublime minds that relate with unfathomable compassion and conceive thoughts that in themselves constitute nothing less than the creation of new worlds. ${ }^{68}$ In any case, Mormon or otherwise, Transhumanists affirm that we can and should change through continued ethical use of technology to expand our abilities.

\section{TRANSHUMANISM}

Transhumanists generally trace our ideological origins to Humanism. Pre-Socratic Greek philosophers looked beyond traditional gods for scientific explanations of the world. Seventeenth-century astronomer Galileo Galilei deferred to human observation when conflicting with ecclesiastical authority.

Eighteenth-century scientist Marquis de Condorcet claimed that medical science could be used to extend human life. ${ }^{69}$

Although most self-identifying Transhumanists are secular, religious Humanism has made substantial contributions to the origins of Transhumanism. Early Christians taught of identifying with Christ and becoming gods. ${ }^{70}$ Thirteenth-century Scholastic theologians continued the recurring synthesis of Christianity with popular science. ${ }^{71}$ Nineteenth-century theologian Nikolai Fyodorov proclaimed that the common task of humanity should be the resuscitative resurrection of our ancestors. ${ }^{72}$ Twentieth-century theologian Pierre Teilhard de Chardin envisioned human evolution, accelerated by technology, moving inexorably toward a conception of God. ${ }^{73}$

An identifiable Transhumanist movement began in the last few decades of the twentieth century. In the 1960s, futurist Fereidoun M. Esfandiary ("FM-2030"), began identifying as "transhumans" those who behave in a manner conducive to a posthuman future. ${ }^{74}$ In the 1980 s, philosopher Max More formalized a

Lifetime (New York: St Martin's Press, 2007).

${ }^{68}$ Anders Sandberg, "The Physics of Information Processing Superobjects: Daily Life Among the Jupiter Brains," Journal of Evolution and Technology (1999), 5.

${ }^{69}$ George Dvorsky, "Marquis de Condorcet, Enlightenment Proto-Transhumanist," Institute for Ethics and Emerging Technology, accessed 1 November 2014, http://ieet.org/index.php/IEET/more/dvorsky20080126.

${ }^{70}$ Justin Martyr, "Dialogue with Trypho," 124; Theophilus of Antioch, "To Autolycus," 2: 27; Irenaeus, "Against Heresies," 4: 38: 3-4; Clement of Alexandria, "Exhortation to the Heathen," 1; Tertullian, "Against Hermogenes," 5; Hippolytus of Rome, "Refutation of All Heresies," 10: 30; Origen, "Commentary on John," 2: 2; Cyprian of Carthage, "Treatise," 6: 11, 15; Gregory of Neocaesarea, "Sectional Confession of Faith," 16; Methodius of Olympus, "Banquet of the Ten Virgins," 8: 8; Antony the Great, "On the Character of Men and on the Virtuous Life," 168; Athanasius of Alexandria, "Incarnation of the Word," 54; Hilary of Poitiers, "On the Trinity," 9: 38; Cyril of Jerusalem, "Catechetical Lecture," 21: 1; Basil of Caesarea, "On the Spirit," 23; Gregory of Nazianzus, "Oration," 2: 22-23; Augustine of Hippo, "On the Psalms," 50: 2; Mark the Ascetic, "To Nicolas the Solitary;" Theodoret of Cyrus, "Letter," 146; Diadochos of Photiki, "On Spiritual Knowledge and Discrimination," 89; Thalassius the Libyan, "On Love, Self Control and Life in accordance with the Intellect," 1: 95-101; Maximus the Confessor, "On Theology," 1: 53-55; John of Damascus, "Exposition of the Orthodox Faith," 2: 12; Theodore of Edessa, "Theoretikon;" Peter of Damaskos, "Treasury of Divine Knowledge 1: Introduction;" and Theognostos, "On the Practice of the Virtues, Contemplation and the Priesthood," 32.

${ }^{71}$ Thomas Aquinas, Summa Theologica.

${ }^{72}$ N. A. Berdyaev, "The Religion of Resusciative Resurrection," accessed 1 November 2014, http://www.berdyaev.com/berdiaev/berd_lib/1915_186.html.

${ }^{73}$ Eric Steinhart, "Teilhard de Chardin and Transhumanism," Journal of Evolution and Technology, accessed 1 November 2014, http://jetpress.org/v20/steinhart.htm.

74 “About FM-2030," accessed 1 November 2014, http://www.fm2030.com/about/. 
Transhumanist doctrine, advocating the "Principles of Extropy" for continuously improving the human condition. ${ }^{75}$ In the 1990s, a group of influential Transhumanists authored the "Transhumanist Declaration," stating various ethical positions related to the use of and planning for technological advances. ${ }^{76}$ Also in the 1990s, philosophers Nick Bostrom and David Pearce founded the World Transhumanist Association, which became the largest network of Transhumanists with membership in the thousands, and later changed its name to Humanity+. ${ }^{77}$ In the 2000 s, technologist Ray Kurzweil published "The Singularity Is Near," popularizing the idea of accelerating technological change. ${ }^{78}$ Also in the 2000s, the Mormon Transhumanist Association became the largest network of religious Transhumanists with membership in the hundreds. ${ }^{79}$

\section{MISRECOGNIZED RELIGIOSITY}

Despite occasional equivocation, ${ }^{80}$ whether among Transhumanists or from external accounts, Transhumanism is not atheism. In fact, recent polls suggest only about half of Transhumanists identify as either atheist or agnostic, and that is down about $15 \%$ from surveys done a decade ago ${ }^{81}$ Given that agnosticism tends to be more prevalent than atheism in most populations, it may be that not even a quarter of Transhumanists are atheists, and the proportion of atheist Transhumanists may be in decline.

What might explain a decline? One contributor could be simply that religious persons are increasingly recognizing compatibility and even complementarity between their religious views and Transhumanism. Another contributor could be that some common Transhumanist expectations, if not aspirations, may be incompatible with atheism. For example, achieving the capacity to simulate or otherwise emulate our evolutionary history may entail that our world was created by beings that qualify as God in some religions. ${ }^{82}$ Perhaps another contributor is that some atheist-inclined Transhumanists have become alarmed by or weary of the fervent anti-religiosity advocated by some atheists. ${ }^{83}$ Having no wish to be associated with that any more than with religious fundamentalism, they might be adjusting their self-descriptions.

Yet another contributor could be that we are beginning to recognize that Transhumanism itself functions as a religion for some of us, and perhaps most especially for some of us that most strongly deny that function. ${ }^{84}$ That is not to claim that Transhumanism is inherently a religion. In itself, the advocacy of

\footnotetext{
${ }^{75}$ Max More, "The Principles of Extropy," accessed 1 November 2014, https://www.scribd.com/doc/203978899/Max-More-The-Principles-of-Extropy.

76 “Transhumanist Declaration," Humanity+, accessed 1 November 2014, http://humanityplus.org/philosophy/transhumanist-declaration/.

77 “About," Humanity+, accessed 1 November 2014, http://humanityplus.org/about/.

${ }^{78}$ Kurzweil, The Singularity Is Near.

79 “About," Mormon Transhumanist Association, accessed 1 November 2014, http://transfigurism.org/pages/about/.

${ }^{80}$ Zoltan Istvan, "Some Atheists and Transhumanists are Asking: Should it be Illegal to Indoctrinate Kids With

Religion?," Huffington Post, accessed 1 November 2014,

http://www.huffingtonpost.com/zoltan-istvan/some-atheists-and-transhu_b_5814484.html.

81 "Who are the IEET's audience?," Institute for Ethics and Emerging Technology, accessed 1 November 2014, http://ieet.org/index.php/IEET/more/poll20130716.

${ }^{82}$ Cannon, "New God Argument."

${ }^{83}$ Giulio Prisco, "Yes, I Am a Believer," Institute for Ethics and Emerging Technology, accessed 1 November 2014, http://ieet.org/index.php/IEET/more/prisco20120523.

${ }^{84}$ Tirosh-Samuelson, "Secularist Faith."
} 
ethical use of technology to extend human abilities need not be religious. However, it nonetheless ends up functioning as religion for some that adopt and identify with the ideology.

There are the sacraments of nutrition supplements, the rituals of cryonics, the prophecies of indefinite healthy life extension, the spirits of substrate independent minds, the apocalyptic and messianic postures toward artificial intelligence, the millennial paradisiacal hope of life and abundance beyond present notions of suffering and poverty, and ultimately the pantheon of posthumanity. While, in the minds of some individual Transhumanists, these may really only be rough analogies between religious and Transhumanist views, they are nonetheless infused with collective strenuosity among some groups of Transhumanists.

In other words, among some Transhumanists, our vision and practice function as religion, perhaps not according to narrow presecular accounts of religion, but rather from broad accounts of the religious phenomenon from deep history through its evolution into popular traditional trappings and on into its emerging postsecular manifestations. ${ }^{85}$ Transhumanism, for some Transhumanists, is postsecular religion, even if misrecognized.

\section{ACCELERATING CHANGE}

In the 1960s, Intel co-founder Gordon Moore observed that the ratio of computing capacity to cost was doubling predictably, every couple years or faster. In other words, a computer built in 1969 had twice as much capacity as a computer built at the same cost in 1968, and over a hundred times as much capacity as a computer built at the same cost in 1962; a computer built in 1969 would also reliably have half the capacity of a computer built at the same cost in 1970, and less than a hundredth the capacity of a computer built at the same cost in 1976 .

That trend, known as Moore's Law, has continued to the present. ${ }^{86}$ Today, a $\$ 150$ smartphone can store about a million times more data and process that data about a thousand times faster than the $\$ 150 \mathrm{~K}$ Apollo Guidance Computer that took astronauts to the moon in 1969. The smartphone also has wireless access to extended computing capacity on the Internet, including powerful systems such as Google, Amazon, and Facebook.

Suppose Moore's Law continues. Within decades, whatever replaces smartphones would have millions, billions, and then trillions of times the overall computing capacity at the same cost. Within a century, $\$ 150$ could perhaps purchase more computing capacity than that of all human brains combined. ${ }^{87}$ Imagine the possibilities.

This short fable might help. A king was deeply grateful to his court mathematician, who had performed great services. He summoned her and asked how he might best reward her. After some consideration, the mathematician told the king that she would be delighted to receive rice, the number of grains to be determined by placing one grain on the first square of a chessboard, two grains on the second square, four grains on the third, and so on, doubling the number of grains for each of the sixty four squares of the

\footnotetext{
${ }^{85}$ Smith, "Secular Liturgies."

86 “Moore's Law and Intel Innovation," Intel, accessed 1 November 2014, http://www.intel.com/content/www/us/en/history/museum-gordon-moore-law.html.

${ }^{87}$ Kurzweil, Singularity, 136.
} 
chessboard. The king was surprised and pressed her to ask for more, but the mathematician resisted, so he commanded her request to be granted.

How much rice did the mathematician request? Visualize it. What do you see? If you are like most of us, and if you have not already formally confronted the natural difficulty of intuiting exponential change, you have dramatically underestimated. The rice requested by the mathematician would fill not only the chessboard, the table, and even the courtroom. It would fill more than the entire kingdom. The mathematician's request would actually cover the entire planet under a kilometer of rice.

If accelerating change continues, our informal intuitive sense of what the world might look like ten, thirty, or a hundred years from now is almost certainly and quite dramatically wrong. Even predictions based on the best social and economic and political theories, if not accounting for accelerating change, would be stunningly incorrect. The future probably will not be even close to what we imagine, if accelerating change persists, and if we do not work to account for that possibility in our expectations.

\section{VISION OF A FUTURE}

Mormon Transhumanists do not have one vision of the future. We have many visions - many dreams. And we express them in many narratives. Here is one, reflecting some common expectations and aspirations, and illustrating parallels between Mormonism and Transhumanism.

Ours is one of innumerable worlds ${ }^{88}$ a childlike telestial world,${ }^{89}$ growing in the fullness of times. ${ }^{90}$ Filled as if by an unstoppable rolling river pouring from the heavens, our knowledge becomes unprecedented. ${ }^{91}$ Nothing is withheld, whether the laws of the earth or the bounds of the heavens, whether there be one God or many gods, everything begins to manifest. ${ }^{92}$ And the work of God hastens. ${ }^{93}$ Repeating the words of Christ, we speak, ${ }^{94}$ and information technologies begin to carry the consolation of compassion around the world. Emulating the works of Christ, we act, ${ }^{95}$ and biological technologies begin to make the blind see, ${ }^{96}$ the lame walk, ${ }^{97}$ and the deaf hear; ${ }^{98}$ agricultural technologies begin to feed the hungry; and manufacturing technologies begin to clothe the naked..$^{99}$ Hearts turning to our ancestors, we remember,

\footnotetext{
${ }^{88}$ Moses 1: 35

${ }^{89}$ Kevin Barney, "The Etymology of 'Telestial'," By Common Consent, accessed 1 November 2014, http://bycommonconsent.com/2010/01/27/the-etymology-of-telestial/.

${ }^{90}$ Ephesians 1: 10

${ }^{91} \mathrm{D \& C} 121: 33$

92 D\&C 121: 26-32

${ }^{93}$ D\&C 88: 73-80

${ }^{94}$ Mark 16: 15

${ }^{95}$ Matthew 10: 8

${ }^{96}$ Alice Park, "Stem Cells Allow Nearly Blind Patients to See," Time, accessed 1 November 2014, http://time.com/3507094/stem-cells-eyesight/.

${ }^{97}$ John Hewitt, "Paralyzed man walks again after surgeons transplant cells from his nose to his spine," Extremetech, accessed 1 November 2014,

http:/www.extremetech.com/extreme/192548-paralyzed-man-walks-again-after-surgeons-transplant-cells-from-hisnose-to-his-spine.

${ }^{98}$ Gordon Rayner, "Moment a deaf woman could hear for first time," The Telegraph, accessed 1 November 2014, http://www.telegraph.co.uk/health/10728006/Moment-a-deaf-woman-could-hear-for-first-time.html.

${ }^{99}$ Jacob 2: 19 and Mosiah 4: 26
} 
and sophisticated machine learning algorithms begin to process massive databases, perhaps to redeem our dead. $^{100}$

As information and biological sciences continue to advance and merge, a biotech revolution becomes as obvious as the computing revolution was at the advent of the Internet. ${ }^{101}$ Synthetic biology restores extinct species, creates new forms of life, and hints at programmable ecologies. Some contemplate prophecies about renewal of our world, ${ }^{102}$ and some ponder scriptures about the creation of whole new worlds - or perhaps their accidental destruction. ${ }^{103}$ Personalized and regenerative medicines begin to restore vitality to the bodies and minds of an older generation. Responding to worries that death may be necessary for meaning, new voices repeat old stories about those who were more blessed for their desire to avoid death altogether. ${ }^{104}$ Reproduction technology permits infertile and gay couples, as well as individuals or groups, to conceive their own genetic children. Some recoil from perceived threats to tradition, while others celebrate perceived gifts to new families. ${ }^{105}$ Weaponized pathogens are a top security risk, threatening pandemics as well as targeted genocides and assassinations. Meanwhile, solar energy is less expensive than any other. And the Internet evolves into a distributed reputation network, expediting the social feedback loop, strengthening incentives for cooperation, and increasing both the reach and the value of relationships. Missionaries find their work more challenging and rewarding than ever before. ${ }^{106}$

Biotech combines with advances in materials and manufacturing sciences to produce a nanotech revolution. ${ }^{107}$ Generally available and affordable atomically-precise printing technologies grant unprecedented access to food, clothing, and shelter. With such abundance, welfare programs solve old problems ${ }^{108}$ but systemic unemployment presents new ones. ${ }^{109}$ Among the wealthy, robotic cells flow through bodies and brains, extending abilities beyond those of the greatest athletes and scholars of history, and further restoring vitality. Most become convinced that we can eventually vanquish that awful monster, death, ${ }^{110}$ while cautionary and critical voices draw increasing attention to persistent and socially-damaging inequalities. ${ }^{111}$ The ability to read and write data to and from every neuron in the brain begins to connect us experientially, both sensorially and emotionally, with each other and with our environment. As spiritual experiences become easily reproducible and malleable, teachers shift focus from general encouragement to careful discernment between helpful and harmful esthetics. ${ }^{12}$ Hijacked motor functions or automated stimulation of pleasure centers in the brain present major psychosocial risks, haunting family relationships and burdening communities. The Internet is a composite of virtual, augmented, and integrated-natural reality. Weaponized self-replicating nanobots are a top environmental risk, threatening consumption of the biosphere. Meanwhile, moon bases facilitate robotic mining of asteroids and initiate construction of colonies in large satellites orbiting Earth and on Mars, reinvigorating

\footnotetext{
${ }^{100}$ D\&C 128: 6-9

${ }^{101}$ Kurzweil, Singularity, 206.

${ }^{102}$ Articles of Faith 1: 10

${ }^{103}$ Moses 1: 38

1043 Nephi 28

${ }^{105}$ D\&C 88: 33

${ }^{106}$ D\&C 14: 3-4

${ }^{107}$ Kurzweil, Singularity, 226.

${ }^{108}$ D\&C 42: 34, 55

${ }^{109} 2$ Nephi 26: 30-31

1102 Nephi 9: 10, 19, 26

${ }^{111}$ D\&C 78: 6

112 Joseph, Teachings, 202.
} 
the pioneer spirit. ${ }^{113}$

Information science, empowered by advances in biotech and nanotech, climaxes in a neurotech revolution. ${ }^{114}$ The functions of the brain and body are virtualized, and we begin extending or transitioning our minds into more robust bodies, biological and otherwise - as innumerable and diverse as the stars. ${ }^{115}$ As the morphological possibility space expands, some warn against desecrating the image of God, and some recall prophecies about the ordinance of transfiguration. ${ }^{116}$ Data storage and materials engineering ensures our minds and bodies are maintained or restored as needed in perpetuity, banishing death as we know it. ${ }^{117}$ Brain and body preservation patients from previous decades are resuscitated. Environmental data mining suggests the possibility of gathering all the information required to reconstruct not only a detailed evolutionary history of our world and civilization, but also complete models of the bodies and brains of our dead ancestors individually. Some conclude this possibility was ordained, before the world was, to enable us to redeem our dead, ${ }^{118}$ perhaps even to perform the ordinance of resurrection. ${ }^{119}$ Diverse forms of artificial and enhanced intelligence, both similar and alien to human, evolve to superhuman capacities. Filled with knowledge and power, ${ }^{120}$ they vie for resources to pursue an increasingly diverse and complex possibility space of goals. Malicious superintelligence is the ultimate security risk. Meanwhile, we encounter each other and, most profoundly of all, we encounter the tangible personification of our world, itself instrumented into an embodiment for a vast mind, in intimate and transformative ways that we did not previously have the anatomical capacity to imagine, except vaguely as sublime compassion and immersive empathy made possible by pervasive experiential interconnectedness.

In that day, ours will be a young terrestrial world, ${ }^{121}$ a millennial paradise. ${ }^{122}$ Technology and religion will have evolved beyond our present abilities to conceive or express, except loosely through symbolic analogies. ${ }^{123}$ We will see and feel and know the messiah, ${ }^{124}$ the return of Christ, in the embodied personification of the light and life of our world, ${ }^{125}$ with and in whom we will be one, ${ }^{126}$ speaking the words and doing the works of Christ: consoling, healing, and raising each other together in the glory of God. ${ }^{127}$ Enjoying a world beyond present notions of enmity, poverty, suffering, and death - the living transfigured and the dead resurrected to immortality - we will fulfill prophecies. ${ }^{128}$ And we will repeat others, forth-telling and provoking ourselves onward and upward, through yet greater challenges, ${ }^{129}$ to

\author{
${ }^{113}$ D\&C 136 \\ ${ }^{114}$ Kurzweil, Singularity, 259. \\ ${ }^{115}$ D\&C 76: 98, 109 \\ 116 Joseph, Teachings, 170. \\ 1171 Corinthians 15: 51-55 \\ ${ }^{118}$ D\&C 128: 22 \\ ${ }^{119}$ Brigham Young in vol. 3 of Wilford Woodruff's Journal, ed. Scott Kenney (Utah: Signature Books, 1985), \\ 323-324. \\ ${ }^{120}$ D\&C 77: 1-4 \\ ${ }^{121}$ D\&C 76: 91 \\ ${ }^{122}$ Articles of Faith 1: 10 \\ ${ }^{123}$ D\&C 1: 24 \\ ${ }^{124} 1$ John 3: 2 \\ ${ }^{125}$ John 8: 12, Mosiah 16: 9, 3 Nephi 11: 11, and D\&C 88: 7-13 \\ ${ }^{126}$ John 17: 20-23 \\ ${ }^{127}$ Matthew 10: 7-8 \\ ${ }^{128}$ D\&C 101: 26-34 \\ ${ }^{129} \mathrm{D} \& \mathrm{C} 43: 31$
}


maturity in a celestial world, ${ }^{130}$ and beyond in worlds without end. ${ }^{131}$

\section{NEW GOD ARGUMENT}

Popular among Mormon Transhumanists, the New God Argument is an argument for faith in God, or trust in posthumanity that may qualify as God in some religions. ${ }^{132}$ The argument does not prove that God exists. Rather, the argument proves that if humanity will not go extinct before evolving into superintelligent posthumanity then, given assumptions consistent with contemporary science and technological trends, superintelligent posthumanity probably is more compassionate than us and probably created our world. The only alternative is that humanity probably will go extinct before evolving into superintelligent posthumanity. In other words, the New God Argument shows that trust in our own superintelligent potential may entail faith in God; and conversely, reasons for skepticism about God may be reasons for skepticism about our own superintelligent potential.

Here is a basic formulation of and elaboration on the argument in four parts: Faith Assumption, Compassion Argument, Creation Argument, and God Conclusion.

The Faith Assumption consists of a single assumption:

F1: humanity will not go extinct before evolving into superintelligent posthumanity (assumption)

The assumption may be false, but we may have moral or practical reasons to behave as if it is true pending conclusive evidence to the contrary, ${ }^{133}$ or at least we may be simply interested in considering the ramifications if it is true. In any case, this assumption is a common aspiration among Transhumanists generally, Mormon and otherwise. ${ }^{134}$

The Compassion Argument consists of two assumptions and a deduction from those assumptions and the Faith Assumption.

CO1: EITHER humanity probably will go extinct before evolving into superintelligent posthumanity OR superintelligent posthumanity probably would not have more destructive capacity than humanity OR superintelligent posthumanity probably would be more compassionate than us (assumption)

CO2: superintelligent posthumanity probably would have more destructive capacity than humanity (assumption)

CO3: superintelligent posthumanity probably would be more compassionate than us (deduction from $\mathrm{CO} 1, \mathrm{CO} 2$, and $\mathrm{Fl}$ )

\footnotetext{
${ }^{130} \mathrm{D} \& \mathrm{C} 88: 25-26$

${ }^{131}$ D\&C 130: 9-11

${ }^{132}$ Cannon, "New God Argument."

${ }^{133}$ Ferdinand Schiller, Studies in Humanism (London: Macmillan and Co., 1907), 430; and James, Will to Believe, 26.

${ }^{134}$ James Hughes, "Executive Summary of the 2007 WTA Member Survey,” accessed 1 November 2014, http://www.transhumanism.org/index.php/th/print/1319/.
} 
The deduction of the Compassion Argument is necessarily true if its assumptions and the Faith Assumption are true. Either or both of the Compassion Argument assumptions may be false, but we may have historical and technological reasons to believe they are true. For example, records suggest that violence has decreased and civil liberties have improved as governments have become more powerful, ${ }^{135}$ and some technologists believe that machine intelligence may destroy us if we do not ensure its friendliness, at least as instrumental cooperation if not as internalized compassion. ${ }^{136}$

The Creation Argument also consists of two assumptions and a deduction from those assumptions and the Faith Assumption.

CR1: EITHER humanity probably will go extinct before evolving into superintelligent posthumanity OR superintelligent posthumanity probably would not create many worlds emulating its evolutionary history OR superintelligent posthumanity probably created our world (assumption)

CR2: superintelligent posthumanity probably would create many worlds emulating its evolutionary history (assumption)

\section{CR3: superintelligent posthumanity probably created our world (deduction from CR1, CR2, and F1)}

The deduction of the Creation Argument is necessarily true if its assumptions and the Faith Assumption are true. Either or both of the Creation Argument assumptions may be false, but we may have technological and mathematical reasons to believe they are true. For example, some technologists believe that computation may enable us to run many family history simulations detailed enough to consist of emulated conscious persons, in which case statistics would show we almost certainly are already living in such a family history simulation ourselves. ${ }^{137}$

Finally, the God Conclusion consists of a single deduction, which is necessarily true if the Compassion Argument and Creation Argument are true.

G1: BOTH superintelligent posthumanity probably would be more compassionate than us AND superintelligent posthumanity probably created our world (deduction from CO3 and CR3)

\section{MORMONISM MANDATES TRANSHUMANISM}

Some Mormon Transhumanists contend that, beyond mere compatibility or even complementarity, Mormonism actually mandates Transhumanism. From this perspective, one can be a Transhumanist without being a Mormon, but one cannot be a Mormon without being a Transhumanist, at least implicitly. Although this is a controversial claim, we can use Mormon scripture to formulate a supporting argument.

The first premise is that God commands us to use ordained means to participate in God's work. This premise is based on scriptures like 1 Nephi 3, which says God prepares ways for us to accomplish God's

\footnotetext{
${ }^{135}$ Steven Pinker, The Better Angels of Our Nature (New York: Viking, 2011).

${ }^{136}$ Nick Bostrom, Superintelligence (Oxford University Press, 2014).

${ }^{137}$ Nick Bostrom, “The Simulation Argument," accessed 1 November 2014, http://www.simulation-argument.com/simulation.html.
} 
commands; ${ }^{138}$ Alma 60, which says God will not save us unless we use the means God has already provided; ${ }^{139}$ and D\&C 58, which says we should engage in good causes without waiting for God to provide specific commands. ${ }^{140}$

The second premise is that science and technology are among the means ordained of God. This premise is based on scriptures like 1 Nephi 17, where God commands Nephi to construct a ship to save his family; ${ }^{141}$ Alma 37, which says God gave Nephi a compass to guide his family to the promised land; ${ }^{142} \mathrm{D} \& \mathrm{C} 88$, where God commands us to study and teach everything from astronomy and geology to history and politics; ${ }^{143}$ and D\&C 121, which says we will learn all the physical laws of the world before attaining heaven. ${ }^{144}$

The third premise is that God's work is to help each other attain Godhood. This premise is based on scriptures like 3 Nephi 12 , where Jesus commands us to be perfect like God; ${ }^{145}$ D\&C 76, which says God would make us Gods of equal power with him; ${ }^{146}$ and Moses 1, which says God's work is to make us immortal in eternal life. ${ }^{147}$

The fourth and final premise is that an essential attribute of Godhood is a glorified immortal body. This premise is based on scriptures like Ether 3, where the Brother of Jared sees that God is embodied; ${ }^{148}$ D\&C 76 , which says God has a body glorified like the sun; ${ }^{149} \mathrm{D} \& \mathrm{C} 93$, which says full joy requires a body, elements are the body of God, and intelligence is the glory of God; ${ }^{150}$ and D\&C 130, which says God's body is as tangible as that of a human. ${ }^{151}$

From these four premises, we can reason.

Because God commands us to use ordained means to participate in God's work, and because science and technology are among those means, we can deduce that God commands us to use science and technology to participate in God's work.

Next, because God commands us to use science and technology to participate in God's work, and because God's work is to help each other attain Godhood, we can deduce that God commands us to use science and technology to help each other attain Godhood.

Finally, because God commands us to use science and technology to help each other attain Godhood, and because an essential attribute of Godhood is a glorified immortal body, we can conclude that God

\footnotetext{
${ }^{138} 1$ Nephi 3: 7

${ }^{139}$ Alma 60: 11, 21-23

${ }^{140}$ D\&C 58: 27-28

${ }^{141} 1$ Nephi 17: 8-11, 16

${ }^{142}$ Alma 37: 38-39

${ }^{143}$ D\&C 88: 78-79

${ }^{144}$ D\&C 121: 26-33

${ }^{145} 3$ Nephi 12: 48

${ }^{146}$ D\&C 76: 58-60, 92-95

${ }^{147}$ Moses 1: 39

${ }_{148}$ Ether 3: 7-16

${ }^{149}$ D\&C 76: 70

${ }^{150}$ D\&C 93: $33-36$

${ }^{151}$ D\&C 130: 22
} 
commands us to use science and technology to help each other attain a glorified immortal body.

This conclusion is both a religious mandate, in that it purports to express the will of God, and a description of the Transhumanist project, advocating the ethical use of technology to expand human abilities. If we arrived at this conclusion by valid reasoning, which we did, and if we began with premises that accurately reflect Mormonism, then Mormonism mandates Transhumanism. 